\title{
2021 Handbook of Florida Water Regulation: Florida Pollutant Discharge Prevention and Control Act ${ }^{1}$
}

\author{
Michael T. Olexa, Tatiana Borisova, and Jana Caracciolo²
}

\section{Preface}

This handbook is designed to provide an accurate, current, and authoritative summary of the principal federal and state (Florida) laws that directly or indirectly relate to agriculture. This handbook provides a basic overview of the many rights and responsibilities that farmers and farmland owners have under both federal and state laws as well as the appropriate contact information to obtain more detailed information. However, the reader should be aware that because the laws, administrative rulings, and court decisions on which this handbook is based are subject to constant revision, portions of this publication could become outdated at any time. Several details of cited laws are also left out due to space limitations. This handbook is provided as an educational text for those interested in water use and water resource issues in Florida.

This handbook is distributed with the understanding that the authors are not engaged in rendering legal or other professional advice, and the information contained herein should not be regarded as a substitute for professional advice. This handbook is not all inclusive in providing information to achieve compliance with the federal and state laws and regulations governing water protection. For these reasons, the use of these materials by any person constitutes an agreement to hold harmless the authors, the UF/IFAS Center for Agricultural and Natural Resource Law, and UF/IFAS Extension for any liability claims, damages, or expenses that may be incurred by any person as a result of reference to or reliance on the information contained in this handbook. Note: UF/IFAS is the acronym for University of Florida, Institute of Food and Agricultural Sciences.

\section{FPDPCA Overview}

The Florida Pollutant Discharge Prevention and Control Act (FPDPCA) was passed in 1970 primarily to prevent vessels from discharging oil or other pollutants while in waters within the territorial jurisdiction of Florida. The legislature enacted FPDPCA in response to major oil spills in Tampa Bay and Jacksonville waters. FPDPCA addresses the threats to Florida jurisdictional waters from spills and discharges of substances and pollutants occurring as a result of procedures involved in the storage, transportation, and transfer of these substances and pollutants between ships, onshore facilities, offshore facilities, and terminal facilities, and from saltwater traps impregnated with pollutants. Note that "pollutants" include oil of any kind and in any form, gasoline, pesticides, ammonia, chlorine, and derivatives thereof, excluding liquefied petroleum gas.

FPDPCA empowers and provides a trust fund, the Florida Coastal Protection Trust Fund (FCPTF), for the Florida Department of Environmental Protection (FDEP) and the Florida Fish and Wildlife Conservation Commission (FFWCC). The sources of funding include, for example, cost of damage to natural resources recovered from

1. This document is FE585, one of a series of the Food and Resource Economics Department, UF/IFAS Extension. Original publication date October 1998. Revised June 2017 and April 2021. Visit the EDIS website at https://edis.ifas.ufl.edu for the currently supported version of this publication.

2. Michael T. Olexa, professor, Food and Resource Economics Department, and director, UF/IFAS Center for Agricultural and Natural Resource Law, and member of The Florida Bar; Tatiana Borisova, associate professor, Food and Resource Economics Department; and Jana Caracciolo, student, Levin College of Law; UF/IFAS Extension, Gainesville, FL 32611.

The Institute of Food and Agricultural Sciences (IFAS) is an Equal Opportunity Institution authorized to provide research, educational information and other services

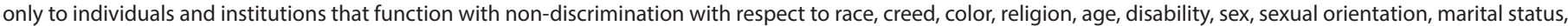

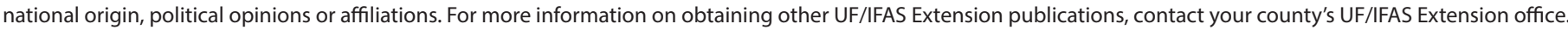
U.S. Department of Agriculture, UF/IFAS Extension Service, University of Florida, IFAS, Florida A \& M University Cooperative Extension Program, and Boards of County Commissioners Cooperating. Nick T. Place, dean for UF/IFAS Extension. 
responsible parties. The fund is intended to regulate, investigate, rehabilitate, and clean up the sites contaminated by the spills and discharges. FPDPCA also extends liability for site pollution to several potential defendants and is a potent measure for forcing responsible parties to contribute to the costs of cleanup. In addition to spill and discharge regulation, FPDPCA also prohibits leaving derelict vessels in Florida waters.

The only expressed exclusion from FPDPCA coverage is the storage or transportation of liquefied petroleum gas or industrial effluents discharged into the waters or atmosphere of the state pursuant to either a federal or state permit (for more information about the permits regulating water pollution discharges, see FE583, Resource Conservation and Recovery Act).

\section{Who enforces FPDPCA?}

FPDPCA is enforced by FFWCC and FDEP. FDEP is the primary enforcer of FPDPCA, under which FDEP issues both (a) the registration certificates and (b) the discharge prevention and response certificates required by FPDPCA. Under FPDPCA, it is FDEP that adopts and enforces the rules necessary to implement FPDPCA, including rules pertaining to

- The procedures and methods for reporting prohibited discharges

- The procedures, methods, and equipment to be used in the removal of pollutants

- The development and implementation of criteria and plans to meet pollution discharges of various degrees

- The creation of a state response team that will create and maintain a contingency plan for handling emergency cleanup, rehabilitation, and wildlife rescue operations

FDEP is also responsible for establishing and maintaining, at certain ports in and outside of Florida, equipment and offices needed to carry out the provisions of FPDPCA. FDEP is tasked with assessing damages caused by a discharge of pollutants and in recovering costs of the damage.

While FDEP is the primary enforcer of FPDPCA, FPDPCA mandates that FFWCC must assist FDEP in both assessing the damages to wildlife caused by a discharge of pollutants and in recovering the costs of the damage. Furthermore, FPDPCA designates FFWCC as the only state agency authorized to remove derelict vessels from public waters, and provides that FFWCC may establish a grant program, funded by FCPTF, to provide grants to all local governments for the removal of derelict vessels from the waters in their areas. FPDPCA mandates the criteria for allocating these grants. For a complete list of the criteria of and procedures to apply for this grant, please contact FFWCC.

\section{What are the requirements of FPDPCA?}

FPDPCA requires that any ship operating in Florida waters that has a storage capacity of 10,000 gallons of pollutants as fuel or cargo must have in writing a ship-specific discharge prevention and control contingency plan. Any such ship must have onboard a discharge officer, designated by the contingency plan, who is responsible for training crew members on how to perform discharge response efforts required by the contingency plan and to coordinate all onboard response efforts in case of a discharge. An adequate contingency plan must include provisions for onboard responses, including notification, pollutant incident assessment, discharge mitigation, and onboard discharge containment. The Florida Statutes clearly state that a contingency plan in compliance with the federal requirement for a ship-specific discharge contingency plan will satisfy this state requirement.

FPDPCA also requires that these ships must maintain discharge prevention gear, holding tanks, and containment gear that meet federal requirements. For a list of these requirements, contact FDEP.

FPDPCA requires that every owner or operator of a terminal facility (onshore and offshore facilities, deepwater ports, pipelines, etc.) must have a discharge prevention and response certificate, issued by FDEP, to legally operate in Florida. Ships, motor vehicles, pipelines, or other related accessories may, at the discretion of the owner or operator, be covered under the discharge prevention and response certificate of the terminal facility responsible for them. The certificate will be valid for one year after the date it is issued, subject to the terms and conditions determined by FDEP to carry out the purpose of FPDPCA.

Applicants for a discharge prevention and response certificate must submit the following information:

- The capacity of the terminal facility and the length of the largest ship docking at or providing service from the facility

- All prevention, containment, and removal equipment (booms, skimmers, pumps, chemicals, etc.) that the facility can access in case of a discharge

- The terms of agreement and the operation plan of any discharge cleanup organization to which the owner or operator of the facility belongs 
A terminal facility cannot obtain a discharge prevention and response certificate unless it has access to containment equipment that is at least five times the length of the largest ship docking at or providing service from the facility, whichever is larger. The containment equipment and an adequate number of trained personnel to operate the equipment must be available to deploy on the water within one hour after discharge is detected. Within a reasonable time period, additional equipment and personnel must be available to reasonably cleanup 10,000 gallons of pollutants unless the terminal facility does not have the capacity to store that much as fuel or cargo and does not service any ships that have the capacity to store that much as fuel or cargo. Cleanup or containment equipment purchased with state funds will not count towards the required amount of equipment. FPDPCA also mandates that terminal facilities must have adequate booming around a ship during the transfer of pollutants (fuel and cargo) to or from the ship.

FPDPCA further requires that each owner or operator of a terminal facility or ship, including any barge, using any port in Florida must establish and maintain insurance pursuant to federal laws and must be able to meet the liabilities that may be incurred under FPDPCA.

\section{Who is liable for cleanup costs under FPDPCA?}

FPDPCA is aimed at several potentially responsible parties, depending on the type of facility that discharges pollutants, as follows:

- In the case of a ship, it is any person owning, operating, or chartering the ship

- In the case of a ship's cargo, it is the owner of the cargo

- In the case of an onshore facility, it is the owner or operator of the facility

- In the case of an offshore facility, it is the owner, lessee, permit holder, or holder of the right of use and easement of the facility

- In the case of a deepwater port licensed under the Deepwater Port Act, it is the licensee

- In the case of a pipeline, it is the owner or operator of the pipeline

If the facility is abandoned, it is the persons who would have been the responsible parties immediately prior to abandonment.

Under FPDPCA, no hold harmless agreements entered into after July 1, 1974 will be effective in exempting any terminal facility or ship from liability for a discharge of pollutants prohibited under FPDPCA.

Because extensive damage to the state's natural resources is the likely result of a pollutant discharge, FDEP is tasked with requiring the responsible party to pay compensation for the damage. The amount of damages is related to FPDPCA's compensation schedule and is based on the volume of the discharge, the characteristics of the pollutant discharged, and the type of natural resource affected. For a list of the criteria of FPDPCA's cleanup standards and the criteria of FPDPCA's compensation schedule for damages to natural resources, please contact FDEP.

\section{What are the penalties under FPDPCA?}

Any violation of a provision of FPDPCA or of a rule or order of FDEP made pursuant to FPDPCA will be punishable by a civil penalty of up to $\$ 75,000$ per violation per day. Each day the violation occurred and continues constitutes a separate offense. Any discharge that is promptly reported and removed or cleaned up by a responsible person in accordance with FDEP rules or that is less than or equal to five gallons of pollutants is exempted from these penalties.

In addition to the above penalty, any person who is responsible for two or more reported discharges within a twelve-month period at the same facility commits a noncriminal infraction (i.e., violation) and faces the following civil penalties:

- For discharges of gasoline or diesel equal to or less than five gallons, $\$ 75$ for each discharge after the first offense

- For discharges of gasoline or diesel over five gallons, $\$ 750$ for the second discharge and $\$ 1,500$ for each subsequent discharge within the twelve-month period

- For discharges of pollutants other than gasoline or diesel equal to or less than five gallons, $\$ 150$ for each discharge after the first offense

- For discharges of pollutants other than gasoline or diesel over five gallons, $\$ 3,750$ for the second discharge and $\$ 7,500$ for each subsequent discharge within the twelvemonth period

The above penalties begin with the second offense and apply regardless of cleanup or notification of a prior violation.

Any owner or operator of a ship who operates in Florida waters without a discharge prevention and control contingency plan in violation of FPDPCA commits a noncriminal infraction and faces a civil penalty of $\$ 5,000$. 
Any owner or operator of a terminal facility operating without a discharge prevention and response certificate in violation of FPDPCA or who violates the terms and requirements of the certificate commits a non-criminal infraction and faces a civil penalty of $\$ 500$.

Any owner or operator of a terminal facility involved in the transfer of a pollutant (fuel or cargo) to or from a ship that is not adequately boomed commits a non-criminal infraction and faces a civil penalty of $\$ 2,500$.

For all the penalties under FPDPCA, any person charged with a non-criminal infraction and facing a civil penalty may

- Pay the civil penalty

- Post a bond equal to the amount of the civil penalty, which is forfeited if they do not appear in county court

- Sign and accept a citation indicating a promise to appear before the county court, which may or may not impose the civil penalty (the county court's ruling can be appealed to the circuit courts)

Any person who refuses to post bond or accept and sign a citation commits a second-degree misdemeanor punishable by a fine of up to $\$ 500$ and/or up to 60 days' imprisonment.

Any person who knowingly makes or causes to be made a false statement in response to FPDPCA requirements before the county or circuit court commits a second-degree felony punishable by a fine of up to $\$ 10,000$ and/or up to 15 years' imprisonment.

Note that misdemeanors are crimes that are punishable by imprisonment of one year or less, and felonies are crimes that are punishable by imprisonment of more than one year. Misdemeanors and felonies are further classified by degrees according to the level of severity, with first degree being the most serious crimes.

\section{What are the defenses to liability under FPDPCA?}

Defenses to liability are limited to the following:

- Acts of God

- Acts of war

- Acts of government (federal, state, county, or municipalities)

- Actions or omissions of a third party not employed by or in a contractual relationship with defendant
To establish entitlement to any of these defenses, violators must plead and prove that they exercised due care with respect to the pollutant concerned, taking into consideration the characteristics of the pollutant, and that they took precautions against foreseeable acts or omissions of others and the foreseeable consequences of those acts or omissions.

These defenses will not apply to violators who fail or refuse to

- Report the discharge as required by law when they know or have reason to know of the discharge

- Provide reasonable cooperation and assistance requested by a state or federal on-scene coordinator in connection with cleanup activities

\section{Sources}

Chapter 376, Florida Statutes, Sections 376.011 to 376.21

\section{Acknowledgments}

The authors are indebted to the personnel of both state and federal agencies who provided their time and advice in the preparation of this handbook. We acknowledge Carol Fountain and Susan Gildersleeve at the University of Florida for their assistance in editing this handbook. We also acknowledge funding received for updating this publication from the James S. and Dorothy F. Wershow UF/ IFAS Center for Agricultural and Natural Resource Law Endowment. 